\title{
DOES ‘BEST PRACTICE’ IN SETTING EXECUTIVE PAY IN THE UK ENCOURAGE ‘GOOD’ BEHAVIOUR?
}

\author{
FINAL SUBMISSION TO \\ JOURNAL OF BUSINESS ETHICS, \\ CORPORATE GOVERNANCE SECTION
}




\title{
DOES ‘BEST PRACTICE’ IN SETTING EXECUTIVE PAY IN THE UK ENCOURAGE ‘GOOD’ BEHAVIOUR?
}

\begin{abstract}
:
We examine how UK listed companies set executive pay, reviewing the implications of following best practice in corporate governance and examining how this can conflict with what shareholders and other stakeholders might perceive as good behaviour. We do this by considering current governance regulation in the light of interviews with protagonists in the debate, setting out the dilemmas faced by remuneration-setters, and showing how the processes they follow can lead to ethical conflicts.
\end{abstract}

Current 'best' practice governing executive pay includes the use of market benchmarks to determine salary and bonus levels, significant levels of performance-related pay, the desire for executives to hold equity in their companies, the disclosure of total shareholder return compared to an index, and a perceived need for conformity, in order to grant legitimacy to policies. Whilst each of these may in some circumstances lead to good practice, each has the potential to cause dysfunctional behaviour in executives.

Overall, we conclude that although best practice might drive good executive behaviour, that coincides with the company’s and key stakeholders’ objectives, there are many reasons why it should not.

Keywords: compensation, ethics, executive, governance, remuneration, stakeholder 


\section{DOES ‘BEST PRACTICE’ IN SETTING EXECUTIVE PAY IN THE UK ENCOURAGE ‘GOOD’ BEHAVIOUR?}

For more than a decade, executive compensation in the United Kingdom (UK), United States (US) and other jurisdictions has attracted unfavourable attention from practitioners, academics and the media, who have focused on the large amounts received by executives, both in absolute terms and in comparison with pay received by employees lower down the corporate hierarchy. Much of this commentary is about whether the level of pay is 'fair', either to employees or to shareholders, who see high executive rewards even when share price performance is poor.

Partly as a result of this attention, the area has been subject to continued regulation, with government directives and voluntary codes focusing on the nature of pay and its disclosure. In recent years, regulation in the UK has attempted to address these concerns by demanding that companies increase the proportion of pay that is performance-related rather than fixed salary, and by increasing the level of disclosure of executive reward. This regulation commenced with the Greenbury Report (1995) and is seen most recently in the Combined Code (2003). However, despite these layers of regulation, we do not know whether the way in which executive pay is set addresses issues of 'fairness' nor, more broadly, how this might impact the behaviour of executive directors ${ }^{\mathrm{i}}$.

This paper asks whether the pay practices, in particular the way that pay is determined, that are regarded as comprising good governance encourage good behaviour. In order to address this question, a view must be taken as to what behaviour is in fact required; in 
other words, what 'good' looks like. We start from the point of view that good behaviour means that the remuneration scheme will encourage executives to act in ways that are most appropriate for the company's circumstances. To some extent, the determination of this depends upon the perspective taken of the firm, be it a shareholder perspective (Friedman, 1962) or a stakeholder one (e.g. Evan and Freeman, 1992): different stakeholders have different needs of the organisation. Our way to resolve this is to refer to the OECD’s preamble to its Principles of Corporate Governance:

Corporate governance involves a set of relationships between a company's management, its board, its shareholders and other stakeholders. ... Good corporate governance should provide proper incentives for the board and management to pursue objectives that are in the interests of the company and its shareholders and should facilitate effective monitoring. (OECD, 2004: 11)

It can be seen that although other stakeholders are considered, the OECD definition clearly privileges the shareholder. Thus, as Wilhelm (1993: 469) states, the best remuneration schemes should reward executives for making decisions in the best interests of shareholders. Accordingly, in this paper we focus largely on the shareholder, and see 'good' in that light. However, given the forthcoming changes to UK company law (Company Law Reform Bill, 2005, 10 (2) (156)) relating to 'enlightened shareholder value', which states that directors should also have regard to the interests of other stakeholders, we do also make reference to how these governance practices can affect other stakeholders. 
The literature on executive pay (reviewed, for example, by Merchant et al., 2003; Werner and Ward, 2004) mostly focuses on pay as an agency issue, in which remuneration contracts are designed to align executives' and shareholders' interests, although some social-psychological issues such as social comparison are researched (O'Reilly et al., 1988). However, these are to some extent static analyses: they use archival data to examine the outcomes of the remuneration-setting process, but not the processes themselves. Indeed, the extant literature contains few papers (for example: McNulty and Pettigrew, 1999; Pye, 2001; Roberts, McNulty, and Stiles, 2005; Perkins and Hendry, 2005) that examine the processes undertaken by boards of directors. Accordingly, our motivation in writing this paper is to look at the processes behind the pay policies and packages, to understand the objectives of the protagonists in setting remuneration, and to highlight the factors that influence their decisions, and the outcomes that result.

To address this issue, and to present an analysis of the impact of the current governance regime and the resulting behaviours it can drive, this paper draws upon the results of interview-based research with protagonists in the remuneration-setting decision in a selection of FTSE 350 companies based in the UK. The aim of the interviews was to determine how pay levels and structures were determined, and the issues considered by the remuneration-setters. The interviews covered the decisions made, and how these decisions were addressed, given the constraints of best practice and corporate governance regulation. The results indicate that some of the practices commonly regarded as good governance may have an unfortunate side-effect of encouraging behaviour that is not 
necessarily in the interests of the company or its stakeholders. Thus we provide empirical evidence to address some of the questions raised, in a US context, by Matsumura and Shin (2005).

There are many papers, by both academics and practitioners, that suggest how remuneration practices might be changed (for example, Lee, 2002; Bebchuk and Fried, 2004). That is not the aim of this paper, and we do not venture into that territory. Our contribution is to set out what is happening, given that little previous research has uncovered how pay is set and the behaviours it drives. We address practice as is, and leave it to others to build upon these findings to recommend changes.

The rest of this paper is organised as follows. The next section briefly sets the context of recent developments in governance in the UK relating to executive directors' pay. We then describe the research approach, and the following sections describe how companies determine pay and how this is affected by considerations of best practice. The final section concludes, discussing the relationship between best practice and good behaviour.

\section{Corporate Governance Requirements Regarding Executive Pay}

The field of governance in the UK has evolved considerably since the Cadbury Report in 1992. Many regulations have impacted on remuneration practices. Current governance regulations specifically relating to executive remuneration include the Combined Code (2003) (“the Code”) and the Directors' Remuneration Report Regulations (Department of 
Trade and Industry (“DTI”), 2002) (“the Report Regulations”). As regards the Code, one section is particularly relevant to this paper:

Levels of remuneration should be sufficient to attract, retain and motivate directors of the quality required to run the company successfully, but a company should avoid paying more than is necessary for this purpose. A significant proportion of executive directors' remuneration should be structured so as to link rewards to corporate and individual performance. $(2003, B 1)$

We note later in this paper the difficulties that companies have in determining pay that is sufficient to attract and retain directors, but not excessive.

The Report Regulations extended the already considerable disclosure required by UK listed companies. Key disclosures for the published remuneration report include:

1. a statement of remuneration policy;

2. details of remuneration committee membership and meetings;

3. advisors to the remuneration committee;

4. details of individual directors' service contracts;

5. a five year performance graph;

6. details and explanation of performance measures for long-term incentives; and

7. details of individual directors' remuneration.

Of these disclosures, items 5, 6 and 7 in particular are pertinent and are discussed in this paper. 


\section{Research approach}

The study reported in this paper examined how executive directors' pay was determined in selected companies. It adopted a multiple company case study approach as suggested by Yin (1994), with the unit of analysis being the company. It is an exploratory study; an appropriate approach given the fact, as stated earlier, that there is little in the extant body of literature that discusses board and committee processes.

The research method was to conduct face-to-face interviews (lasting on average an hour) with protagonists in the remuneration-setting decision. 40 interviews were conducted in all. 35 of these were at 12 FTSE 350 companies; the five other interviews, to gain wider views of the process, and to confirm initial findings, included headhunters, an institutional representative and two focus groups ${ }^{\mathrm{ii}}$. The fieldwork was mainly carried out in 2002 and 2003. Table 1 sets out the roles of the corporate participants and the number of respondents from each firm ${ }^{\mathrm{iii}}$.

\section{TABLE 1 ABOUT HERE}

The case companies were selected in a variety of ways. The first six were cold-called, the selection being made based on data obtained from the PricewaterhouseCoopers Corporate Register (a commercial database of companies and directors) dated June 2001. Companies 7 to 10 joined the study through contact, via one of the early interviewees, with a group of executive remuneration professionals in FTSE 100 companies. Interviews at companies 11 and 12 arose after one of the authors had presented some 
early findings at a corporate governance conference (Bender, 2003). The main criteria for selecting companies for the research were (a) that they appeared to follow the governance regulations laid down in the Code; and (b) that their non-executive directors (NEDs) between them had experience of several different companies. A further criterion was the desire to include some utilities in the sample, as utilities provide an interesting context to explore executive pay in the UK, for historical and commercial reasons. ${ }^{\text {iv }}$

The interviews were semi-structured, but wide-ranging. An interview protocol was drawn up based on an extensive literature review, with the broad aim of establishing the processes by which the directors' remuneration policies and packages were determined in the selected companies. The focus was on the individual companies and what was done there, rather than asking interviewees to comment on best practice, although inevitably best practice was discussed. The interview protocol was piloted at two companies (included in the 12), and was not changed for the larger study.

In addition to the interviews, documentation such as remuneration committee meeting minutes and consultants' reports was obtained from five of the companies (the others would not make such information available). Furthermore, financial statements (including the published remuneration reports) were obtained for all companies for the previous, current and subsequent years. These various forms of documentation were used before the meetings to set a context for individual discussion, and after the meetings to confirm, where possible, details of schemes and processes that had been discussed. Further detail on the research method is given in Bender (2004). 
Before setting out the results of the research, it is useful to put the study in context. The participating companies were to some extent self-selecting. About 50 companies were approached for the study; only 12 agreed to become involved ${ }^{\mathrm{v}}$. It is reasonable to assume - both a priori and from later discussions with the interviewees - that the case companies became involved because they were interested in governance issues and believed that their own practices would stand up to research scrutiny. Given the research approach, and the fact that there is no intention to generalise to an overall population from this work, that does not present a problem. It is, however, important, as the sample population can therefore be assumed to include only 'good' companies, and individuals who were trying to follow what they perceived as good practice. For a discussion on the ethics of executive pay, this is a useful starting point.

\section{Stakeholders in the pay-setting decision}

UK listed companies have formally-constituted remuneration committees of NEDs to determine executive pay. In all of the case companies, the committee membership generally drew on the advice and expertise of the HR support staff and the company secretary. However, the CEO and chairman were often in attendance at the committee meetings, and provided input into their agendas. The contribution of these participants was considered important, as the view of the executives who lead the business is generally seen as critical in designing schemes to meet corporate strategy. (This is considered good practice under the Code (2003, B2).) 
In determining executive pay, remuneration committees have to have regard to several different constituencies: the board (representing the company), executives, shareholders and possibly others. Although shareholders, particularly institutional shareholders, were considered pivotal in most of the companies, the level and structure of remuneration were set with a view to satisfying three specific stakeholders. As one of the interviewees stated:

What you're trying to do here is to identify a solution that is right for three parties: the investors, the company, and the managers. And all the time, they are concerned with those three dimensions. And if it isn't satisfactory to any one of those three, it's not satisfactory. There's no point in coming up with something which the company thinks is wonderful, the investors think is wonderful, which has no value to the directors.

HR professional

It was clear that these three stakeholders were considered in remuneration-setting in all the case companies, although in some more weight was given to the executives, and in some the shareholders were seen as key. Under the Combined Code (2003, B2.4) shareholders should be invited specifically to approve all new long-term incentive schemes and significant changes to existing schemes. Accordingly, there was formal and informal consultation with major shareholders and their representative bodies (the Association of British Insurers and the National Association of Pension Funds).

Employees and customers are also stakeholders, and although they were not specifically consulted about executive pay, their likely views were sometimes considered. For example, the remuneration practices and disclosures of utilities are governed by the UK's 
various utilities acts, which meant that all of the utilities in the in the sample had customer- and employee-related performance measures attached to their bonus awards. Furthermore, some interviewees referred to the way in which executive pay would be perceived by these stakeholders.

You have in a remuneration structure to try and ensure that you've got fairness. That's fairness to the individual and fairness to the organisation. And the organisation means all the constituent parts: the customers, the other members of staff, and the shareholders.

CEO (non-utility)

Thus remuneration policies did appear in these case companies to take account of stakeholder interests, although this was not a universal approach.

\section{How best practice affects executive pay}

The interviewees discussed various ways in which 'best practice' affected pay levels and structures. These included using market benchmarks to set pay and bonus levels; the need to be fair, and to be seen to be fair to the various parties; the ubiquitous use of performance-related pay; the choice of performance measures and targets, including the use of total shareholder return (TSR) as a performance measure and the perceived need for conformance in determining pay policies; and the requirement for executives to hold equity in their companies. Each of these is discussed in turn. 


\section{The use of market benchmarks}

Although executive pay is perceived to be high as compared to that of the general population, it is impossible to state whether, generally, it is 'too high'. No clear, workable guidelines have ever been established to determine what levels of pay would be appropriate, even though several researchers have considered this subject. For example, Cox and Power (1991) and Perel (2003) both report the attitudes of various stakeholders in the executive pay debate, but come to no conclusion. Nichols and Subramaniam (2001) discuss the argument that executives are overpaid, and that the amount of such overpayment is increasing, and then compare that with the argument made by others, that executives are paid a fair amount. They conclude that both viewpoints are unsatisfactory; over- or under-payment can only be judged in relation to others, and there is no clear standard for comparison. Interestingly, Moriarty (2005) does set out a case for executives being overpaid, using a range of different comparators. However, he fails to establish a basis to determine the 'correct' level of pay.

In practice, pay is generally set with reference to sector-based remuneration surveys that measure companies on size, which sets a benchmark that can be justified to investors.

Several issues arise from this use of market surveys to set pay. In addition to the aspects of fairness, discussed next in this paper, are matters of the ratcheting up of pay, and the need to retain good executives. These are all linked, as remuneration committees and their advisors appreciate the problems of ever-increasing pay levels, but worry about losing valuable employees. 
When we look at salaries we look at base pay, and we're very careful to construct something that looks exactly competitive with our competitors. ... once we do incentives we also do look at what the market is paying for equivalent jobs. ... But we are saying to ourselves 'does this look right?'. Because as I said before, our executives, male and female, always have the opportunity of taking something else, given their skills. And certainly, comparability of the package is an important factor in that.

Committee chairman

This extract highlights one of the main worries of remuneration committees - that they may lose good people by paying below the market. However, some authors believe the argument on retention to be overdone, in that executives paid less than the market are unlikely to leave. For example, Wilhelm (1993: 480) comments that:

... surveys are bogus and CEO mobility is really low. Surveys presume that underpaid CEOs have many better-paying CEO jobs available to them. Openings are in fact scarce and many CEOs wouldn't be hired because their skills are limited mainly to one company or industry...

The ratcheting up of executive pay (Hamilton, 1995; Moules, 2004) has to a large extent been driven by that most important of governance principles - disclosure. Following the Greenbury report (1995), which required companies to disclose the pay details for each director separately, individuals and companies had a clear benchmark. Several interviewees expressed sentiments similar to the following.

In my view, by far the biggest input on the steady increase in executive director pay over the last decade has been the Greenbury report. Publication of directors' remuneration has 
had an inevitable upward push on executive pay. It would be interesting to know how many of your remuneration committees were prepared to say that they would aim their target remuneration in the bottom quartile.

Headhunter

Such an increase in pay resulting from disclosure is in line with the observations of Matsumura and Shin (2005), who commented, in a US context, that although additional disclosures could mean improved governance, they could also lead to a "beauty contest" in which levels of compensation increased as firms desired their executives to be amongst the highest paid.

The level of total pay also reflects the amount of bonus earned and the long-term award, and these too have been increasing in recent years, following the market up in the same way as has salary. The following comment is representative.

The reason we went from $40 \%$ to $60 \%$ [bonus cap] was because we were advised by [consultancy] that that was what the typical market company was doing. And therefore we just thought that we were falling in line with market practice. And I think that was true.

Committee chairman

This increase in variable pay levels has a multiplier effect on the overall package.

Many of the interviewees did comment that compensation was 'too high', although none could suggest a mechanism to reduce the acceleration of executive pay, and none was willing to be the first company to put the brakes on. There was, however, one exception 
to this. In one company, in one year, the CEO prevented the remuneration committee from implementing a survey-based pay rise that he thought (based partly on a conscious regard to the ongoing political debate about executive pay) was too high. Instead, he took soundings from colleagues at other companies, and concluded that a general inflation increase would be more appropriate than the sums suggested by the surveys.

Overall, the participants were well aware of the problems caused by continually increasing levels of executive pay, and understood that the market comparisons and full disclosure were at least in part a cause of this. However, they were unable or unwilling to take action to limit the rise in executive salaries and bonuses, for fear of losing valuable employees. Using the language of the Code (2003, B1), pay levels were set to attract and retain directors, but it was difficult to establish what level would be "more than is necessary”.

\section{The need for fairness}

Related to the above is the need for fairness in setting remuneration at senior levels. Executive pay has to be fair both to the executives and also to the shareholders to whom belong the company's residual profits: excessive remuneration reduces these profits. As an example of the latter, in one company the executive bonus was reduced by the remuneration committee, despite the targets being met, because a poor acquisition had led to an erosion of shareholder value, and the committee took the view that it was appropriate that the executives share the shareholders' loss. ${ }^{\text {vi }}$ However, overall, fairness to the executives featured more in our interviews than fairness to shareholders. 
As Bloom (2004) points out with regard to employees in general, fairness may be critical to a well-designed compensation scheme. Bloom suggests several criteria for fairness, including fair pay for fair work (with better performers receiving more), and procedural fairness in allocating pay between employees. He notes that compensation systems "may also be important signals of the values, morals, and virtues upon which the organization operates" (2004: 150). The interviewees in this study reflected Bloom's view of the many aspects of fairness, referring separately to three ways in which the executive compensation needed to be fair, as set out below.

\section{(a) Fairness between different executives in the same company}

One aspect of fairness related to principles of distributive and procedural justice (Adams, 1963; Bloom, 2004). The pay differential between members of the executive management team has to be perceived as fair, and performance-related pay has to go to those who perform well, in order to differentiate the contributions of managers.

One, we actually wanted to ensure that we did introduce this element of variable pay to incentivise people, and therefore we wanted to ensure that we paid everybody a fair rate for the job, but that those who achieved most had the ability to increase their reward.

HR professional

This sentiment, that fair pay would reflect the differing contributions of individuals, was expressed by several of the interviewees.

(b) Fairness between executives and their peers in comparable companies 
Equity theory (Adams, 1963) suggests that the managers compare their roles and contributions, and their pay, with those of their peers, and will be satisfied if the ratios of work inputs to pay outcomes are about the same. Remuneration-setters were very conscious of this need for comparability, both in levels of pay (as evidenced by the universal use of remuneration surveys) and in the ability to generate large bonuses through performance-related elements.

What [he] wants and expects is to be paid fairly. He would regard being paid fairly in two ways. One, that the basic amount he gets is reasonably comparable with those that he regards as his peers outside. And the second thing he'd expect is that if he and the company perform better, he gets paid more. Now that is what he would regard as being treated fairly. So if he didn't get that he would regard himself as being treated unfairly.

HR professional

This was elegantly summed up by one CEO:

If salaries for the average FTSE chief executive were half as much, then relative to each other, they would still be more concerned about that relativity than they would about whether it's half.

CEO

This links back to the use of executive pay surveys discussed earlier. It highlights the fact that fairness in pay is defined in a relative manner, rather than as an absolute.

(c) Fairness between executives and workers lower down the hierarchy 
Although the pay multiple between executives and other employees is the focus of much external comment (for example Moules, 2004), interviewees varied in their attitudes to how much this mattered.

One interviewee had strong views about the need to consider pay rates throughout the company:

Every statement talks about people being our most important asset, etc. It's about time the feet followed the words, quite frankly. In this company our executive pay is probably 8 to 9 times the average pay in the company. I think that's probably justifiable, maybe about right. But when you get to the kinds of levels that you're talking about in some companies, how are you going to motivate people to feel part of the team, part of the enterprise, something you can actually relate to and invest your discretionary effort in? Because that's what you're trying to capture in the way you manage people. It's giving the extra bit of effort.

HR professional

However, such remarks were not common, and it was more usual for interviewees to comment that the pay differential through the organisation was not a matter for the committee to consider. This was explained by one committee chairman as follows.

Oh, I don't think we've got those sort of formula [relating executive pay to average or minimum wages] in place. Because I think the top end is driven by assessment of what the market would pay for that post, and probably the next 50 posts below that are also market related. The bottom end is related to the annual pay round, and that's mainly inflation linked rather than comparator linked. And then the bits in the middle get sorted out in a similar way. But we do obviously - one of the debates we had when we were setting [CEO's] salary last year was how is this going to be viewed by the guy [working on the shopfloor]? Can we justify it to him? That was very much in the conversation. So it's 
certainly not done in isolation. But the top is driven by market forces and the bottom end is driven by national pay and conditions, which are going on at the time.

Committee chairman

In the light of the earlier discussion on the need to retain good executives, such comments are understandable, even if they have led to the disassociation of executive pay levels from those of other employees. In the discussion of fairness, perceived commercial imperatives meant that fairness between different hierarchical levels of the company was regarded as less significant than fairness to executives and shareholders.

\section{The use of performance-related pay}

As discussed earlier, executive remuneration in the UK generally comprises a base salary plus both short- and long-term performance-related elements (New Bridge Street, 2004a, 2004b). The short-term element, normally an annual bonus scheme, will often include both corporate and individual performance targets. The longer-term elements might include a share option scheme or another form of long-term incentive plan ('Itip'), often using restricted shares. In addition, executives might receive perks and a pension. The research focus was on the salary, bonus and long-term remuneration; in common with much other research in this field (e.g. Murphy, 1999: 2517; Werner and Ward, 2004: 217), little attention was paid to perks and pensions.

The use of performance-related pay (PRP) is ubiquitous in UK listed companies (New Bridge Street, 2004a,2004b). Various reasons are given for this (Bender, 2004), 
including the desire to motivate performance, the need to be fair to employees, good HR practice, and the need for corporate legitimacy. But does PRP encourage good behaviour?

Frey and Osterloh (2005) argue persuasively that using a high level of PRP results in managers acting selfishly and against the shareholders' interests. Citing Enron, WorldCom, etc, they suggest that PRP is one factor that has caused some of the corporate frauds and excesses of recent times. They argue that companies should focus on intrinsically motivated corporate virtue rather than relying on externally-provided incentives.

A quote from one of the interviewees, whilst not typical of other conversations, illustrates a problem of such variable pay:

Human nature is very variable from individual to individual. So how they work differently, at its worst, will be people become overly obsessed with what their reward is and what is required to deliver that. And that might not always be in the best interests of the organisation as a whole. And the obvious example of that -- well, there's several of them -but in retail you fight for floorspace. And you might wish to have more floorspace than somebody else so as to deliver your sales targets, even though somebody else might get a better return from it. The other one that's common, I'm not saying that it happens a lot here, but I'm sure it did a bit last year, is that if you're well in excess of your target coming up to year-end then you might as well bring forward some of your costs and spend some money, which of course depresses the overall profit but still means your area is okay. By depressing the overall profit you can actually have an adverse effect on somebody else. 
As stated, such comments about PRP were rare, and indeed, that interviewee went on to discuss his belief that most individuals do see the wider picture, to benefit the organisation.

One finding of the research was that remuneration packages and policies are often changed, particularly if the PRP elements do not pay out, or pay out too little (Bender, 2005). An argument made to justify this follows expectancy theory (Vroom, 1964; Lawler, 1991), which maintains that PRP will only motivate if (a) the employee sees the amount to be earned as worthwhile, (b) believes that the award will be paid if the targets are achieved, and (c) considers those targets to be achievable. The research findings showed instances of changes to pay schemes for both (a) and (c), with the amount of potential reward being increased, and measures or targets being amended if they were unlikely to be met.

One HR professional justified such changes with the comment that:

The committee decided that to have something that frankly was not incentivising was a weak and blunt instrument.

In the same vein, the minutes for another company noted that:

$\ldots$ the committee was of the view that the restricted share plan in its present form was not incentivising... 
In both companies the schemes were subsequently changed. Whilst this makes sense from a motivational viewpoint, it could create a moral hazard if employees come to expect that under-performing will lead to targets being restated.

An issue relating to this changing of schemes and targets is the re-pricing of share options that are underwater. This practice is not common in the UK, and of all the interviewees, only one was fully in favour of re-pricing; the rest were mostly against. However, as these out-of-the-money options were often supplemented by the issue of new share options at the lower current price, there is a strong argument that this too can create a moral hazard, as the executives end up holding the new, cheaper options as well as the originals (Arya and Sun, 2004).

\section{Measuring and reporting total shareholder return}

A commonly-used performance measure for ltips is total shareholder return (TSR). This measures the return to shareholders over a fixed period (commonly three years) and compares this to the TSR from a group of comparable companies, or an index. Normally, if a company earns TSR lower than the median of its group, the ltip shares will not vest; vesting is in proportion to the company's position on a TSR ranking, with full vesting for upper quartile performance.

A problem with TSR is that the company may be at the mercy of market sentiment, particularly if it benchmarks against an index such as the FTSE 100 and is in an out-offavour sector. Also, share prices can move for reasons unconnected with the directors' or 
company’s performance: one HR director complained that although his company's share price had risen on the delivery of their own good results, it had then fallen because a competitor released bad news into the market. This had no effect on his company's performance, but did affect their TSR.

The interviewees were very aware of this problem, and commented that this performance measure, the use of which is often seen as good governance because it reflects what the shareholders receive, can be de-motivating for executives who may have little control over it. One consultant reflected other interviewees in his comment:

But the longer you go out, I think the less sharp an incentive it is. Particularly when it's share price, there are so many different factors that are going to influence what the share price does.

Consultant

Another impact of TSR, not directly commented upon by any interviewee, is that the reverse can happen, and executives can receive an undeserved reward. For example, when Philip Purcell left his job as Morgan Stanley's chief executive the share price rose significantly (Partnoy, 2005): he would be able to sell his shares at a greater profit, solely because the market was pleased by the change of management.

A further problem with TSR is that it is complex to calculate. This has two impacts. One is an HR problem in that it can be difficult to motivate executives based on a measure they do not fully understand, and against which they cannot easily determine progress. 
Also, the TSR figures can be manipulated. Such manipulation can be in two ways. One NED, an ex finance director himself, pointed out that the company executives could time when to issue news to the market to guide expectations, thus managing the share price at the margin (as discussed by Aboody and Kasznik, 2000). And a consultant pointed out that the calculation of TSR can be done in various ways (e.g. spot prices or average prices) to lead to different results. (In fairness, that consultant also pointed out that his firm does not revise the TSR calculation methodology to suit executives’ wishes.)

Thus an apparently objective measure, theoretically aligned with value for shareholders, may not be as useful as it first appears.

Jensen (2004) writes about the agency costs of overvalued equity and points out that executives whose shares are overvalued have an incentive to defend that unrealistic share price, which can lead to fraud or bad practices. Compensation that is based in any way on the share price (including share options) will only exacerbate this.

A further point on TSR is relevant. The Report Regulations (DTI, 2002) demand that companies disclose a chart showing the TSR of the company over a five year period against the TSR of an appropriate index (e.g. the FTSE 100). Although such disclosure is useful to investors, in practice there could be an adverse effect. Although the graph is for a five year period (which sits oddly with the reality that most companies' long-term schemes are for three years), a new graph will be produced each year, for the preceding five years. Thus it is not necessarily the company's long term shareholder value that is 
being managed but, possibly, its short term share price, with the need to show a satisfactory chart each year.

Even if there were no need to display a chart, this problem might still exist. Best practice is to make a new award every year under the long-term scheme (options or ltips). This makes good sense, as it averages out movements in a cyclical business, and provides a 'handcuff' to retain executives who always have two years' incentives to come. Nevertheless, it means that a three-year period ends each year, with the incentive to manage the year's performance to trigger vesting of each separate award.

\section{Performance measures: disclosure and conformity}

An agency theory approach (Jensen and Meckling, 1976) implies that managers will strive to meet the relevant performance criteria in order to achieve additional reward. Many (for example Davis et al., 1997; McConvill, 2005) would argue with this basic premise, taking exception to the one-dimensional view of Economic Man driven only by financial reward. We have great sympathy with these views. However, given the reality that much of the regulation surrounding executive remuneration appears to be driven by an agency theory approach, we ground our analysis in that school of thought.

In order for performance-related pay to be beneficial to the company, the performance criteria must be valid. This means, in particular, that the measures must be suitable for the business, and the targets must be appropriate to the corporate goals. Measures that are mis-aligned will lead to executives acting in a way that does not add value; targets 
that are too low will not enhance performance, and those that are unrealistically high will demotivate. Thus, setting appropriate measures and targets is one of the most challenging aspects of pay design (Gomez-Mejia and Wiseman, 1997).

The interviewees were aware of these issues, and many commented on the need to balance short and long term incentives, and to balance financial and non-financial measures.

There are two particular issues peculiar to the design of executive incentives that relate to best practice in corporate governance: the need for disclosure of performance measures; and the desire for conformity, to establish the legitimacy of a remuneration policy.

The Report Regulations (DTI, 2002) state that details must be given of performance measures and targets relating to share options or other long-term incentive schemes. Such details should include an explanation of why these conditions were chosen and methods of assessing performance against these conditions. Furthermore, the Combined Code (2003: B2.4) states that companies must obtain the agreement of investors for their long term incentive schemes, which means that a dialogue will be entered into with key shareholder and institutional bodies.

This disclosure of performance measures and targets represents good governance practice, and has many advantages for investors. For example, Buckley (2004) discusses how J. Sainsbury, a UK supermarket chain, withdrew its chairman's bonus because 
investors argued that the underlying targets were insufficiently stretching. Without sufficient disclosure, this institutional action might have been less effective.

However, such disclosure can have unexpected consequences. One case company was reluctant to link measures and targets very closely with the corporate strategic plan. They argued that although such linkage could be good for performance, confidentiality concerns meant that they were not prepared to share this information with shareholders, and so could not use the measures.

Another aspect of the institutional interest in performance measures came in discussions at one company about a pending change to a scheme. Previous years' bonus measures had included a subjective assessment by the remuneration committee as to how well the executives had done in the round. This was being changed, replaced with more objective measures. An interviewee suggested that the changes were not necessarily to the benefit of the company, but done in order to increase the legitimacy of the plan in the eyes of 'box tickers' in the institutions.

This perceived preference for 'hard' measures is also shown in the reluctance of some companies to use broader measures of corporate social responsibility (CSR) in executive pay. Although all of the utilities had such measures (as mentioned earlier, they are required to do so under the utilities acts), some other companies chose only to measure financials. In a discussion with the HR manager of a company which appeared to have a strong (unmeasured) CSR ethos, the following explanation was given for this. 
It hasn't come up as a common discussion point in terms of moving towards some form of balanced scorecard. I think one of the reasons is that there is a lot of scepticism within and without the company in terms of valid measurement and calibration. And in many ways the pressures that are being put on remuneration committees in order to only pay for performance would mean that you actually probably want schemes where there is as little discretion as possible. And with those sort of plans, unless you begin to start seriously measuring intangibles, which you can do of course.... Let's say that you'd wanted to recognise that we'd introduced a major board committee for corporate social responsibility, and that the board itself ought to have 20 percent of its annual incentive reward on how we do against these measures. We'd then have to define the measures, get agreement on them, calibrate them. And then if they are not clearly quantifiable have a way of working out how well people have done.

HR professional

It is thus possible that the design of executive pay schemes means that CSR issues are being side-lined in some companies; good governance practice leading to an outcome that many stakeholders might find undesirable.

Surveys by New Bridge Street (2004a, 2004b) show how similar performance measures are throughout the FTSE 350. One question asked of all the interviewees in this study was whether, if they found a measure that was perfect for the company but totally unique, they would use it for their executive remuneration packages. Many were nervous of such novelty as it would be difficult to explain to the remuneration committee (by the HR professionals) and to the institutions (by the committee). Indeed, an institutional representative commented that they would be suspicious of any new measures - "there's 
an instinctive tendency to mistrust new measures and then to analyse them away until they resemble more traditional schemes”. The following comment is typical.

Well I think we would... I'm just thinking about the committee, and how it responds to innovation. I think the committee would be prepared to consider, I'm not saying we'd necessarily do it. But I think we'd look. It would need to be something very special, clearly. And something which I felt that we could actually go to the City and explain and they would find acceptable. But I would have thought that there's a lot of companies out there, and if there were these sort of novel things around, people would have thought of them by now.

Company chairman

Thus it can be seen that at the executive director level performance measures may be chosen that are not necessarily the most appropriate to meet the company's objectives, but do confer legitimacy and avoid disclosure of sensitive information.

In addition to determining the proportion of directors' remuneration that is to be performance-related, and the measures to use, remuneration committees need to ensure performance targets are set that will motivate directors towards desired performance. This is not always easy: many studies (e.g. Healy, 1985; Murphy, 2001) indicate that performance targets may be gamed, and so not achieve their desired outcomes. Furthermore, Jensen (2003) gives examples of how paying people for budget-based targets can lead to false budgets and poor business decisions. Although most interviewees stated that this did not happen in their companies, one did suggest that there might be an impact. 
So when the operating plan is set, you will end with, in very loose terms, a profit target for the year end. And that profit target will be the one against which your achieved level of bonus will be, and then there will be a sliding scale up from that, in excess of that. So there is a disincentive to have too stretching a profit target, because it will very quickly be potentially demotivating if you know you've not hit it. But it does mean that if you just took away all thoughts of reward, if suddenly you could change somebody's mind and say I only want to operate for the good of the company and the shareholders, then I'm not sure you'd come up with exactly the same operating plan.

Company secretary

A further issue as regards performance targets mirrors the fact mentioned earlier that many companies have the same performance measures. Many also have the same targets, for example as regards growth in earnings per share as a measure attached to the vesting of share options (New Bridge Street Consultants, 2004b). Such similarity of targets is inappropriate given that companies face different growth conditions and different stock market expectations. Often, merely achieving the targets set will not add value for shareholders (Conyon et al., 2000: 494) despite the fact that the company appears to be following best practice.

\section{Executive shareholdings}

One of the arguments of agency theory is that share ownership by the executives can reduce the underlying agency problem. This is borne out in studies such as those by Hermalin and Weisbach (1991) or Morck et al. (1988), both of whom find that, up to a certain level, company performance increases with executive share ownership. Thus 
executive share ownership is widely seen as a good thing. In line with this approach, the Combined Code (2003, Schedule A) encourages the holding of company shares by executives, and it is becoming common for companies to devise ways of facilitating this. Of the 12 case companies, four had definite rules for executive shareholdings (for example, that the CEO should hold shares valued at at least twice his/her salary) and two had a voluntary guideline.

In nine companies an element of the annual bonus had to be deferred into shares in the company, which would vest in two or three years, often with the company adding a matching number of shares if certain performance targets were met. This too was designed to align executives with shareholders:

We felt that that would demonstrate externally a much stronger commitment to the business if you had to invest in the first place into it.

HR professional

\begin{abstract}
Although both types of scheme result in the executives holding shares it is interesting to note that they have different shapes and can led to different outcomes. One remuneration consultant summed this up when discussing a share-match scheme:

And the last one was to put in an arrangement which encouraged people, in fact required people to invest some of their bonus in the company's shares. And that gave them a better alignment with shareholders, but gave them an awful lot of upside if they did well with the business.
\end{abstract}

Consultant 
Because the share match can lead to a much greater shareholding, theory suggests that it should provide a greater incentive, and it might give executives more of an incentive to take risks than would the simple ownership of shares. This may in some instances be seen as a good thing. Shareholders (although not other stakeholders such as employees) quite often want executives to take risks, to complement their own diversified investment strategies.

However, financial theory suggests that it is illogical to demand that executives, with undiversified jobs, hold a great part of their wealth tied up in their own companies. Although this does appear to align them with shareholders, to quote one interviewee, "no sane investment advisor would suggest that at all”. An executive in a failing company, whose personal wealth was significantly tied to that company's share price performance, may have an incentive to distort results: the example of Bernie Ebbers at WorldCom may illustrate this (Bebchuk and Fried, 2003; Sonnenfeld, 2004).

Furthermore, as mentioned earlier when discussing TSR, executives have the ability to manipulate share price at the margin. They are also able to time share awards or option exercises to benefit their own personal wealth. For example, Yermack (1997) found, in a US study, that option awards were timed to coincide with favourable movements in stock prices. Thus schemes which are designed to award shares or options to executives, with the aim of increasing their shareholdings, can be gamed. 


\section{Discussion and conclusions: Does best practice encourage good behaviour?}

This paper addresses the issue of how setting executive pay in accordance with good governance practice can influence the executives' behaviour, either for good or otherwise. It does this by presenting the results of interview-based research with 40 participants, representing 12 FTSE 350 companies and some other protagonists in the executive pay debate in the UK. The nature of the research is such that the companies and interviewees only agreed to participate if they had an interest in corporate governance, the implication being that those concerned believe their governance practices to be good. Accordingly, the research results are not, and were never intended to be, generalisable to a wider population, but they do show how 'best practice' has been operationalised in specific companies.

This paper builds on a vast body of statistical research in the field, and adds to the body of knowledge by providing a rich insight into the executive remuneration-setting process, showing in detail the considerations that remuneration committees need to address and the problems they face.

Best practice in setting executive pay requires market benchmarking of pay levels, a significant performance-related element in the pay structure, objective performance measures, and substantial disclosure. These structures have all been adopted for valid reasons, to encourage transparency in this critical area of corporate governance, and to align executive behaviour with the needs of the company. But the findings of this research indicate that these practices, whilst no doubt addressing some problems with 
governance, have also led to a continued upward ratchet in pay, and pay structures and performance measures that can be gamed, and may have less to do with a company's strategic objectives than with gaining legitimacy in the eyes of key stakeholders.

Good behaviour means that the remuneration scheme will drive behaviour that meets the needs of the stakeholders in the most appropriate way for the company's circumstances. It further implies that the behaviours that the scheme is trying to influence will in fact deliver the outcomes sought. In practice, in this paper, 'good' behaviour mainly addresses the needs of shareholders, although other direct stakeholders (e.g. employees and customers) are considered.

The findings of this research show that the process by which board remuneration is set has been driven by corporate governance requirements. As such there is the risk that remuneration becomes homogenised in order to be legitimate and that there is little focus on the specific objectives on the firm. Further, companies with a desire to act for the benefit of a wider range of stakeholders may be constrained by the need to adopt recognisable performance measures rather than specifically-tailored CSR measures.

'Long term' schemes generally run for only three years, often less than a complete business cycle. This is compounded by the fact that a new long term incentive is awarded every year, and performance graphs are produced for each five-year period, which means that the long term focus can in fact be compromised by the need to reach a series of short term goals. The focus on performance-related pay can lead to an unhealthy focus on the 
share price or profits, as can the requirement for executives to hold a proportion of their wealth in their own companies, thus limiting their diversification opportunities and increasing their personal risk.

There remains the issue of whether the total level of pay is fair, and to whom. Fairness is a relative term, rather than an absolute: there is no correct number for executive pay. We found that in practice, 'fairness' mostly means fairness to the executive in comparison to his/her peers - this drives the amount needed to pay what it takes to get and retain the right individual. Thus a purported market seems to determine the remuneration level whether or not society agrees that this is fair.

Many of the recent developments in corporate governance have been introduced to drive out certain bad behaviours - yet this does not guarantee 'good' behaviour. Compliance with regulation does not ensure an ethical approach, and even a well-intentioned scheme can result in dysfunctional behaviour by executives. Indeed, one of the interviewees referred to an effective performance-related pay system as the equivalent of the Holy Grail - something much sought-after but not yet found.

This study does not find evidence that current practice in corporate governance always drives bad behaviour; but it does show that the system results in incentives that could lead executives towards behaviours that are not in the interests of shareholders or other stakeholders. In summary, we conclude that best practice might drive good behaviour, 
but strict adherence to an ever-increasing range of governance regulations means that this relationship should not be taken for granted.

\section{Acknowledgements}

The financial support of the P D Leake Trust (a charity associated with the ICAEW) is gratefully acknowledged. The Centre for Business Performance manages all grant applications.

The authors wish to thank participants at the 16th Annual Conference of the International Association for Business and Society (2005) and the $27^{\text {th }}$ Annual Congress of the European Accounting Association (2005) for their helpful comments on earlier drafts of this paper. We are also very grateful for the suggestions of the three anonymous reviewers. 


\section{Abbreviations}

\begin{tabular}{|l|l|}
\hline CEO & Chief Executive Officer \\
\hline Code & The Combined Code (2003) \\
\hline CSR & Corporate social responsibility \\
\hline DTI & Department of Trade and Industry \\
\hline HR & Human Resources \\
\hline Ltip & Long term incentive plan \\
\hline NED & Non-executive director \\
\hline Report Regulations & Directors' Remuneration Report Regulations \\
\hline UK & United Kingdom \\
\hline USA & United States \\
\hline
\end{tabular}

\section{References}

Aboody, D. and Kasznik, R.: 2000, “CEO Stock Option Awards and the Timing of Corporate Voluntary Disclosures”, Journal of Accounting and Economics 29(1), 73-100.

Adams, J.S.: 1963, “Towards an Understanding of Inequity”, Journal of Abnormal and Social Psychology 67(3), 422-436.

Arya, A. and Sun, H-L.: 2004, "Stock Option Repricing: Heads I Win, Tails You Lose”, Journal of Business Ethics 50(4), 297-312.

Bebchuk, L. and Fried, J.: 2003, “Executive Compensation as an Agency Problem”, Journal of Economic Perspectives 17(3), 71-92. 
Bebchuk, L. and Fried, J.: 2004, Pay without Performance : The Unfulfilled Promise of Executive Compensation (Harvard Business School Press: Boston).

Bender, R.: 2003, “How Executive Directors' Remuneration is Determined in Two

FTSE 350 Utilities”, Corporate Governance: An International Review 11(3), 206-217.

Bender, R.: 2004, "Why Do Companies Use Performance-Related Pay for Their Executive Directors?” Corporate Governance: An International Review 12(4), 521-533.

Bender, R.: 2005, “Onwards and Upwards: Why Companies Change their Executive Remuneration Schemes, and Why This Leads to Increases in Pay” Presented at the Annual Congress of the European Accounting Association, Gothenburg, May 2005.

Bloom, M.: 2004, “The Ethics of Compensation Systems”, Journal of Business Ethics 52(2), 149-152.

Buckley, S.: 2004, "Sainsbury Board Pulls Back On Bonus Payment To Davis", Financial Times $9^{\text {th }}$ July.

Cadbury: 1992, "Report of the Committee on the Financial Aspects of Corporate Governance” (Gee and Co.: London).

Combined Code: 2003, “The Combined Code on Corporate Governance” (Financial Reporting Council: London).

Conyon, M.J., Peck, S.I., Read, L.E. and Sadler, G.V.: 2000, “The Structure of Executive Compensation Contracts: UK Evidence”, Long Range Planning 33(4), 478-503. 
Cox, C. and Power , S.: 1991, “Executive Pay: How Much is Too Much?”, Business Ethics September/October.

Davis, J.H., Schoorman, F.D., Donaldson, L.: 1997, “Towards a Stewardship Theory of Management”, Academy of Management Review 22(1), 20-47.

Department of Trade and Industry: 2002, “Statutory Instrument 2002 No. 1986: The Directors’ Remuneration Report Regulations 2002” (DTI: London).

Eisenhardt, K.M.: 1989, “Building Theories from Case Study Research”, Academy of Management Review 14(4), 532-550.

Evan, W.M., and Freeman, R.E.: 1993, “A Stakeholder Theory of the Modern Corporation: Kantian Capitalism”, in T.L. Beauchamp and N.E. Bowie (eds), Ethical Theory and Business, (Prentice-Hall, Englewood Cliffs N.J.).

Frey, B.S. and Osterloh, M.: 2005, “Yes, Managers Should be Paid Like Bureaucrats”, Journal of Management Inquiry 14(1), 96-111.

Friedman M.: 1962, Capitalism and Freedom (University of Chicago Press, Chicago).

Gomez-Mejia, L.R. and Wiseman, R.M.: 1997, “Reframing Executive Compensation: an Assessment and Outlook”, Journal of Management 23(3), 291-374.

Greenbury, Sir Richard: 1995. “Directors’ Remuneration: Report of a Study Group Chaired by Sir Richard Greenbury”. (Gee and Co., London).

Hamilton, K.: 1995, “Greenbury's Report 'Will Push Up Pay”, The Sunday Times, $26^{\text {th }}$ November.

Healy, P.M.: 1985, “The Effect of Bonus Schemes on Accounting Decisions”, Journal of Accounting and Economics 7(1-3), 85-107. 
Hermalin, B.E. and Weisbach, M.S.: 1991, "The Effects of Board Composition and Direct Incentives on Firm Performance”, Financial Management 20(4), 101112.

Jensen, M.C. and Meckling, W.H.: 1976, “Theory of the Firm: Managerial Behaviour, Agency Costs and Ownership Structure”, Journal of Financial Economics 3, 305-360.

Jensen, M.C.: 2003, “Paying People to Lie: The Truth about the Budgeting Process”, European Financial Management 9(3), 379-406.

Jensen, M.C.: 2004, “The Agency Costs of Overvalued Equity and the Current State of Corporate Finance”, European Financial Management 10(4), 549-565.

Lawler, E.E. III: 1991, “The Organizational Impact of Executive Compensation”, in F.K. Foulkes (ed), Executive Compensation, A Strategic Guide for the 1990s (Harvard Business School Press, Boston).

Lee, P.: 2002, “Not Badly Paid But Paid Badly”, Corporate Governance: An International Review 10(2), 69-74.

Matsumura, E.M. and Shin, J.Y.: 2005, “Corporate Governance Reform and CEO Compensation: Intended and Unintended Consequences”, Journal of Business Ethics, 62, 101-113

McConvill, J.A.: 2005, “Of Stewards, Surfboards and Homo Sapiens: Reflections on the Regulation of Contemporary Corporate Governance” http://ssrn.com/abstract $=660762$

McNulty, T. and Pettigrew, A.: 1999, “Strategists on the Board”, Organization Studies 20(1), 47-74. 
Merchant, K.A., Van der Stede, W.A. and Zheng, L.: 2003, "Disciplinary Constraints on the Advancement of Knowledge: The Case of Organizational Incentive Systems”, Accounting, Organizations and Society 28, 251-286.

Morck, R., Shleifer, A. and Vishny, R.: 1988, "Management Ownership and Market Valuation: an Empirical Analysis”, Journal of Financial Economics 20(1/2), 293-316.

Moriarty, J.: 2005, “Do CEOs get Paid Too Much?”, Business Ethics Quarterly 15(2), 257-281.

Moules, J.: 2004, “Pay Gap Widens as Directors Cash In on Performance-Related Perks”, Financial Times, $8^{\text {th }}$ October.

Murphy, K.J.: 1999, "Executive Compensation”, in O. Ashenfelter and D. Card (eds), Handbook of Labor Economics, Volume 3B (Elsevier, Amsterdam).

Murphy, K.J.: 2001, “Performance Standards in Incentive Contracts”, Journal of Accounting \& Economics 30(3), 245-278.

New Bridge Street Consultants: 2004a, "Survey of Annual Bonus Schemes in FTSE 350 Companies”, December, London.

New Bridge Street Consultants: 2004b, "Paying for Performance: Executive LongTerm Incentives in FTSE 350 Companies”, October, London.

Nichols, D. and Subramaniam, C.: 2001, “Executive Compensation: Excessive or Equitable?”, Journal of Business Ethics 29(4), 339-352.

OECD: 2004, "Principles of Corporate Governance" (OECD, Paris) http://www.oecd.org/dataoecd/32/18/31557724.pdf 
O'Reilly, C.A. III, Main, B.G. and Crystal, G.S.: 1988, “CEO Compensation as Tournament and Social Comparison: A Tale of Two Theories”, Administrative Science Quarterly 33(2), 257-274.

Partnoy, F.: 2005, “A Serious Question for all the Overpaid Bankers”, Financial Times $4^{\text {th }}$ August.

Perel, M.: 2003, “An Ethical Perspective on CEO Compensation”, Journal of Business Ethics 48(4), 381-391.

Perkins, S.J. and Hendry, C.: 2005, “Ordering Top Pay: Interpreting the Signals”, Journal of Management Studies 42(7), 1443-1468.

Pye, A.: 2001, "Corporate Boards, Investors and Their Relationships: Accounts of Accountability and Corporate Governing in Action”, Corporate Governance An International Review 9(3), 186-195.

Roberts, J.D., McNulty, T. and Stiles, P.: 2005, "Beyond Agency Conceptions of the Work of the Non-Executive Director: Creating Accountability in the Boardroom”, British Journal of Management 16(S1), S5-S26.

Sonnenfeld, J.A.: 2004, “Good Governance and the Misleading Myths of Bad Metrics”, Academy of Management Executive 18(1), 108-113.

Vroom, V.H.: 1964, Work and Motivation (Wiley, New York).

Werner, S. and Ward, S.G.: 2004, "Recent Compensation Research: An Eclectic Review”, Human Resource Management Review 14(2), 201-227.

Werner, S. and Ward, S.G.: 2004, "Recent Compensation Research: An Eclectic Review”, Human Resource Management Review 14(2), 201-227. 
Wilhelm, P.G.: 1993, “Application of Distributive Justice Theory to the CEO Pay Problem: Recommendations for Reform”, Journal of Business Ethics 12(6), 469-482.

Yermack, D.: 1997, “Good Timing: CEO Stock Option Awards and Company News Announcements”, The Journal of Finance 52(2), 449-476.

Yin, R.K.: 1994, Case Study Research: Design and Methods (Sage Publications, London). 
Table 1 Company interviewees by job description

\begin{tabular}{|c|c|c|c|c|c|c|c|c|}
\hline Co & $\begin{array}{l}\text { HR (human } \\
\text { resources) } \\
\text { Professional }\end{array}$ & $\begin{array}{l}\text { Committee } \\
\text { chairman }\end{array}$ & $\begin{array}{c}\text { Non- } \\
\text { Exec. } \\
\text { Director }\end{array}$ & Consultant & CEO & $\begin{array}{l}\text { Company } \\
\text { secretary }\end{array}$ & $\begin{array}{l}\text { Company } \\
\text { chairman }\end{array}$ & Total \\
\hline 1 & 2 & 1 & 1 & 1 & 1 & & & 6 \\
\hline 2 & 1 & 1 & 1 & 1 & 1 & & & 5 \\
\hline 3 & 1 & & & & & & & 1 \\
\hline 4 & 1 & 1 & & & 1 & & & 3 \\
\hline 5 & 1 & & 1 & 1 & & 1 & 1 & 5 \\
\hline 6 & 2 & & & & & & & 2 \\
\hline 7 & 1 & 1 & 2 & 1 & 1 & 1 & & 7 \\
\hline 8 & 1 & & & 1 & & & & 2 \\
\hline 9 & 1 & & & & & & & 1 \\
\hline 10 & 1 & & & & & & & 1 \\
\hline 11 & & & & & & 1 & & 1 \\
\hline 12 & & 1 & & & & & & 1 \\
\hline Total & 12 & 5 & 5 & 5 & 4 & 3 & 1 & 35 \\
\hline
\end{tabular}

Of the case companies, nine were from the FTSE 100 and three were FTSE 250.

\footnotetext{
${ }^{\text {i }}$ As this paper refers to UK legislation, the word 'director' on its own is used synonymously with 'executive'. Outside directors are known as 'non-executive directors'

ii The interviews were focused around the following questions: (A) Your thoughts on the debate about the level and structure of executive directors' remuneration (6 questions addressing issues of level and structure, performance and motivation); (B) How the company arrived at its remuneration policies (11 questions addressing the conduct of committee meetings, the roles of the different parties, matters considered and then rejected, time lines of decisions, comparative pay throughout the organisation); and (C) How the company's remuneration policies compare to other companies of which you are aware (3 questions addressing level and structure of pay, and 'good' or 'bad' practice). Interviewees were also asked to complete a short questionnaire, ranking the various factors that might impact on their pay decisions (e.g. company size, profitability, strategy, individual director needs, etc.)

iii Eisenhardt (1989) states that in case study research, where the focus is on understanding the dynamics present in single settings, there is no ideal number of cases for a study (such as there might be in statistical analysis), but that a number between four and ten usually works well.

${ }^{\text {iv }}$ It was primarily the generous packages awarded to directors of the newly-privatised utilities that led to the setting up on the Greenbury study group, which produced its influential report on directors' remuneration in 1995. Utility directors suffered at that time from the 'fat cat' label, although much has changed in the sector since then. Furthermore, current legislation governing the utilities demands that they disclose how (if at all) executive remuneration is linked to operational service standards, the aim being to encourage such a link. Four utilities were included in the 12 case companies. The utility interviewees were
} 
very aware of their companies' 'fat cat' history, but otherwise there were no other differences between the utilities and other case companies.

${ }^{\mathrm{v}}$ The exact number of companies approached is unknown to the authors, as the group of remuneration professionals was circularised by the interviewee contact and we had no access to their details. 25

companies were contacted directly by the researchers.

${ }^{v i}$ One could of course argue that any scheme that was due to pay out despite such an erosion of shareholder value was poorly designed anyway. However, that is not the focus of this paper. 